\title{
PURCHASING POWER PARITY AND THE REAL RAND-DOLLAR EXCHANGE RATE
}

\author{
O A Akinboade* and D Makina
}

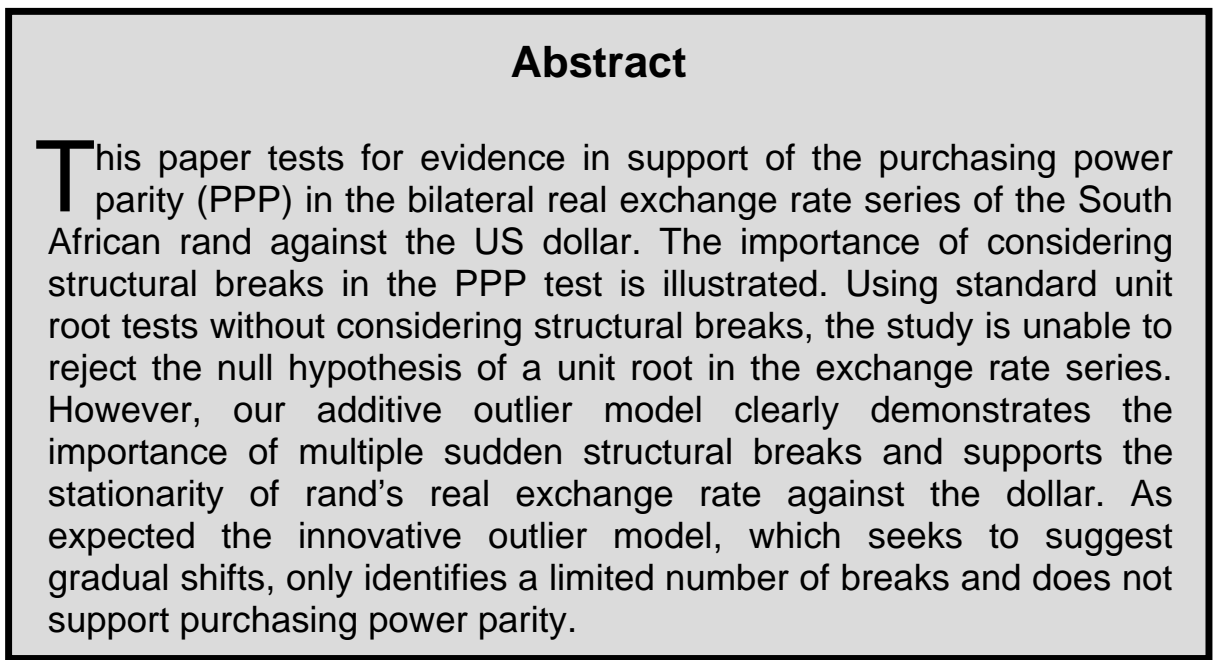

\section{Introduction}

Testing for evidence in support of purchasing power parity (PPP) is popular in international finance literature. It gains importance to policy making as it can be used as a prediction model for exchange rates and for judging the degree of currency misalignment. As such, many exchange rate theories employ the notion of PPP in their construction. The theory's absolute version states that the purchasing power parity (PPP) exchange rate is the exchange rate that would make the purchasing power of a unit of a currency the same in two countries if expressed in terms of one common currency. Under these conditions the same basket of goods and services in both countries should cost the same when expressed in terms of the same currency. On the other hand, the relative version of the PPP theory stipulates that nominal exchange rates change over time such that the price of the same basket of goods in the two economies concerned changes at the same rate. One important implication of the PPP is that the real exchange rate should not change starting from an equilibrium position. If the real exchange rate is constant, then its movement will be viewed as deviations from PPP. In other words, real exchange rates could be considered to be mean- reverting. Should that be the case, PPP would serve as a good approximation of economic behaviour in the long run. If indeed exchange rates are mean reverting then decision makers will then be able to make predictions about future movement in the exchange rate or decide on fixing parities

\footnotetext{
* Respectively Department of Economics and Department of Finance, Risk Management and Banking, University of South Africa, Pretoria 0001, Republic of South Africa.

Email: akinboa@unisa.ac.za
} 
between currencies based on some exchange rate derived based on the real exchange rate. On the other hand, if the real exchange rates are not mean-reverting then PPP would not be of much help to decision makers.

The PPP theory is important because most theories of international finance are based on it. For instance, PPP is related to interest rate parity theory and the international Fisher (IFE) theory. The interest rate parity theory focuses on why the forward rate differs from the spot rate and the degree of difference that should exist. The IFE theory just like PPP focuses on how a currency's spot rate will change over time. Whereas PPP theory suggests that the spot rate will change in accordance with inflation differentials, IFE theory suggests that the spot rate will change in accordance with interest rate differentials. However, PPP is related to IFE because inflation differentials influence the nominal interest rate differentials between two countries.

Rigorous empirical examination of the theory began to appear in the 1960s, when evidence was found supporting PPP over long periods of time (see, for example, Friedman and Schwartz, 1963). During the past three decades, empirical evidence on the validity of PPP has been mixed, and there have been heated debates about the validity of PPP such that professional confidence in the theory has experienced considerable ups and downs. With the move to flexible exchange rates in the early 1970 s, it was generally assumed that the exchange rate would quickly adjust to changes in relative price levels. However, the high volatility of exchange rates, in both nominal and real terms, rendered PPP theory almost untenable. Dornbusch (1976) proposed an overshooting model, temporarily mitigating some unease in the literature. He argued that stickiness of goods prices and continuously clearing asset markets are the main reasons for deviations from PPP. Before the mid-1980s empirical tests were concerned with simple specifications of PPP that centred on coefficient restrictions, using the methods of ordinary and generalised least squares. These tests tended to strongly reject PPP except for hyperinflation countries. This line of research reached its high-water mark in the early 1980s with a paper published by Frenkel (1981) entitled "The Collapse of Purchasing Power Parities during the 1970s". It is now widely agreed that such straightforward tests for PPP, which Froot and Rogoff (1995a,b) termed the "Stage-One tests", took no account of non-stationarity in exchange rates and relative prices, and thus produced possibly spurious results.

Using time-series techniques, many PPP studies in the 1980s tested the efficientmarkets version of PPP (that is, the hypothesis of the random walk behaviour in real exchange rates), but could not reject the null of a random walk (see, e.g., Adler and Lehman, 1983, Meese and Rogoff, 1988, and Mark, 1990). There was also a sizeable amount of work that failed to find cointegration between nominal exchange rates and relative prices (see, e.g., Corbae and Ouliaris, 1988, Enders, 1988, and Patel, 1990). The failure of PPP to pass empirical scrutiny further sapped confidence in the practical usefulness of the theory.

The late-1980s saw a rebirth of interest in PPP, mainly due to the advent of unitroot econometrics. As conventional unit-root tests have low power, researchers 
have circumvented the problem by using (i) longer periods of data; and (ii) crosscountry-time-series analysis, known as 'panel data' techniques. Research from long-horizon data generally finds increasing evidence of convergence to PPP.

Recently there has been increasing evidence from studies that employ the panel test procedure in favour of mean reversion of real exchange rates in industrial countries (Wu, 1996; MacDonald, 1996; Oh, 1996; Jorion and Sweeney, 1996; Papell, 1997 and Papell \& Theodoridis, 1998; 2001). As regards developing countries there has been mixed evidence. For instance, Bahmani-Oskooee (1993) who utilised the Engle-Granger technique on 25 less developed countries found evidence for PPP only on few cases among major trading partners. Mahdavi and Zhou (1994) who applied the Johansen technique on a sample of less developed countries concluded that PPP is likely to hold among high inflation countries. Salehizadeh and Taylor (1999) utilised the cointegration technique and found mixed results in a sample of 27 developing countries. More recently, Hassanain (2003) who examined the mean reversion behaviour of the real exchange rate using a non-linear IV unit root test for a panel of 41 developing countries rejected the null hypothesis of unit root for the full panel and for sub panels for Africa, Latin America and for high inflation countries.

A number of empirical studies show that the behaviour of the exchange rate is in fact nonlinear in nature (Lukkonen et al., 1988; Granger and Terasvirta, 1993; Micheal et al., 1997; Taylor and Peel; 1997; Sarno, 2000a, b; Sarantis, 1999; Taylor and Peel; 2000; Baum et al., 2001; Liew et al., 2002). In most of these studies the exchange rate adjustment is shown to vary nonlinearly with respect to the size of deviation, that is, for small deviations from equilibrium, the exchange rate may adjust very slowly or not adjust at all, but for large deviations, it adjusts rapidly to its equilibrium. This adjustment is well characterized by the smooth transition autoregressive (STAR) process. The STAR model is an advanced econometric model that is deemed most appropriate in capturing the behaviour of the exchange rate, which adjust every moment but the speed of adjustment depends on the variations of the exchange rate from its equilibrium level. Under the assumption of this STAR model, the exchange rate is globally stable (mean reversion) due to its strong tendency to return to its equilibrium level, although non-stationarity (non-mean reversion) may be detected locally. Global mean reversion of the exchange rate has been verified empirically using sample data of various rates. Examining the real exchange rate behaviour in a Middle Eastern country, Sarno (2000b) for instance, provides empirical evidence that deviations from the Purchasing Power Parity (PPP) revert to a constant equilibrium level in a nonlinear fashion. Baum et al. (2001) arrive at similar conclusion for developed countries. Liew et al. (2002) also report the nonlinear adjustment of Asian nominal exchange rate deviations towards PPP while Baharumshah, Liew and Lau (2004) provides robust evidence of non-linear mean reversion in the real exchange rates of four major ASEAN countries based on formal nonlinear unit root test of Sarno (2001).

The aim of this paper is to test for evidence in support of the purchasing power parity theory using traditional unit root tools and more recent techniques that 
consider the presence of structural breaks. Since the work of Perron (1989), it has been shown that ignoring structural changes could lead to the erroneous acceptance of the null hypothesis of the existence of unit roots in real exchange rate series. The rest of the paper is organized as follows. Section 2 traces the evolution of the randdollar real exchange rate. Section 3 discusses data sources and unit root tests for evidence in support of purchasing power parity. In Section 4, we tested for the presence of outliers in our real exchange rate series. Results of our analysis are presented in Section 5, while the last section concludes the paper.

\section{The evolution of rand-dollar exchange rate}

South Africa has experienced frequent exchange rate regime changes over the years and in some periods has maintained pegged exchange rates. Most of the rand's history incorporated a dual exchange rate system. The financial rand acted as a shock absorber for the commercial rand which exchanged at a significant discount of between 15 percent and 55 percent to the commercial rand over the thirty years that this mechanism was in place. On different occasions during the 1970's the commercial rand was fixed to the US dollar or to the British pound and fluctuated in line with the value of these currencies. In September 1975, specifically, government devalued the rand against the pound by 18 percent

The commercial rand was fixed until May 1979. Thereafter, it underwent a system of managed float. In 1980 the rand hit its highest level ever of USD 1,35 to the rand. During the debt standstill crisis in the 1980's both the commercial and financial rand plummeted, with the rand losing over 30 percent of its real trade weighted value in a matter of months. The only comparable decline of such magnitude in the real effective exchange rate of the rand was witnessed in November and December 2001.

Economic sanctions were lifted in the early 1990s. The dual exchange rate system was abolished in March 1995 and for a period of eleven months thereafter the unified rand was stable at around R 3,60 to the US dollar. The first major weakness in the currency emerged in 1996 when Mr Trevor Manuel took over as Minister of Finance. 1996 marked a "sell-off" of the rand with the rand losing 20 percent of its value reaching $\mathrm{R} 4,50$ against the US dollar by June 1996. During 1996 the currency declined by 15,6 percent (year-on-year) against the US dollar. However, the rand quickly stabilised and even improved slightly after the release of government's GEAR (Growth, employment and redistribution) macro-economic strategy.

Around September/October 1997, the world witnessed the start of the so-called financial systemic crises in most south-east Asia and in 1998 Russia experienced a debt crisis. The contagion arising from these crises hit all emerging markets in May 1998. Therefore 1998 saw another major collapse of the rand such that the rand declined by over 20 percent in real terms. Faced with acute pressures on the rand in the foreign exchange market during May 1998, the Reserve Bank embarked 
on a policy of intervening in the foreign exchange market in support of the rand ${ }^{1}$. This led to a dramatic fall in the country's gold and foreign exchange reserves ${ }^{2}$. While the foreign reserves position and foreign credit lines outstanding hardly changed, the net commitments of the Reserve Bank to sell dollars forward increased to $\$ 22,5$ billion $^{3}$. The authorities also increased interest rates aggressively at the time. The prime overdraft rate went up from 18,25 percent in March 1998 to 25,5 percent in August of that year.

During 1999, the currency recovered somewhat and its real effective rate actually increased during the first six months of 1999 by more than 5 percent. Through 1999, the rand exchanged in a broad band between R5,50 and R6,40 to the US dollar. The long slide in the rand began with the rand trading at R6,12 at the turn of the new millennium. Over the twenty-one month period from the beginning of 2000 to 11 September 2001 the rand maintained an almost consistent and fairly welldefined declining trend against the US dollar. During the year 2001, the rand exchanged for R7,6 against the US dollar and depreciated to over R8,0 during the second quarter. The rand depreciated further to R8,52 against the US dollar on 11 September, 2001; R9,03 at the end of September and R10,27 at the end of November. By December 2001, the rand was exchanging for R13,84 to the US dollar.

Table 1: Annual change (\%) in the average exchange rate of the rand

\begin{tabular}{l|c|c}
\hline & $\mathbf{1 9 8 0 - 9 5}$ & $\mathbf{1 9 9 6 - 2 0 0 1}$ \\
\hline Nominal effective rate & $-7,9$ & $-7,7$ \\
\hline Real effective rate & 0,4 & $-4,0$ \\
\hline Rand-dollar & $-8,0$ & $-12,4$ \\
\hline Rand-Pounds & $-6,5$ & $-11,0$ \\
\hline Rand-Euro & $-10,1$ & $-6,7$ \\
\hline Rand-Yen & $-12,6$ & $-8,3$ \\
\hline
\end{tabular}

Overall, a number of possible political and financial events dates summarized below could have affected the evolution of the rand exchange rate over the study period.

\footnotetext{
${ }^{1}$ This involved substantial sales of dollars out of the foreign reserves, as well as intervention in the forward rand-dollar market by buying dollars spot and selling dollars forward, and then selling the spot dollars acquired to support the rand.

${ }^{2}$ While the gross foreign reserves of the Reserve Bank rose marginally from R32,7 billion to R32,8 billion in May 1998, the use of foreign credit lines rose from R9,2 billion to R17,1 billion, while the Bank's commitments to sell dollars forward rose by $\$ 5,1$ billion to $\$ 17,9$ billion. In June 1998 , further sharp falls in the foreign reserves position materialised.

${ }^{3}$ Between October 1998 and September 2001 some $\$ 18$ billion of foreign exchange was drained from the market by the Reserve Bank to reduce the Net Open Forward Position (NOFP).
} 
Table 2: Selected dates and events in South Africa

\begin{tabular}{|c|c|}
\hline Date & Events having potential of creating structural break in the country \\
\hline 1983:February & Financial rand abolished \\
\hline 1984 & The legalization of black trade union movement in the country \\
\hline 1985 & $\begin{array}{l}\text { United Nations resolved to impose economic sanctions on the } \\
\text { country }\end{array}$ \\
\hline 1985:August & Temporary closure of foreign exchange market \\
\hline 1985:September & $\begin{array}{l}\text { South Africa imposed a system of exchange control and debt } \\
\text { repayment standstill }\end{array}$ \\
\hline 1986 & $\begin{array}{l}\text { USA and Britain imposed economic sanctions on South Africa. } \\
\text { Large corporations disinvested from South Africa. } \\
\text { Emigration of white professionals increased. }\end{array}$ \\
\hline 1986: March & $\begin{array}{l}\text { Interim arrangements with respect to certain debt repayments were } \\
\text { concluded with bank creditors. The arrangements to be effective } \\
\text { until June } 1987 \text {. }\end{array}$ \\
\hline 1986: June & State of emergency declared in order to deal with political crisis \\
\hline 1990:February & Release of Nelson Mandela from prison \\
\hline 1992: March & The last whites only referendum approved majority rule \\
\hline 1992: December & Most of the sanctions imposed on South Africa were lifted. \\
\hline 1994: April & $\begin{array}{l}\text { First democratic election, ushering in the African National } \\
\text { Congress }\end{array}$ \\
\hline 1995: March & Unification of the dual exchange rate of the rand \\
\hline 1998 & Russia debt crisis and the first Rand crisis \\
\hline 1998: May & $\begin{array}{l}\text { Concerns about the possibility of higher U.S. interest rates and the } \\
\text { effects of the continuing economic crisis in Asia weighed on the } \\
\text { market. }\end{array}$ \\
\hline 1998: June & $\begin{array}{l}\text { Net open forward position increased from } \$ 12.8 \text { billion in April to } \\
\$ 22.5 \text { billion in June. }\end{array}$ \\
\hline 1998: July & $\begin{array}{l}\text { Former Labor Minister Tito Mboweni was appointed the nation's } \\
\text { central bank governor, replacing Chris Stals in August } 1999 . \\
\text { The rand plummeted by } 37 \% \text { against the US dollar under } 5 \text { months. } \\
\text { By December the rand plummeted on average by } 20 \% \text { against the } \\
\text { US dollar. }\end{array}$ \\
\hline 1999: April & $\begin{array}{l}\text { Second democratic election, The African National Congress } \\
\text { consolidates it majority in parliament }\end{array}$ \\
\hline $\begin{array}{l}\text { 2001: } \\
\text { November/December }\end{array}$ & $\begin{array}{l}\text { The Rand plunged by } 40 \% \text { against key convertible currencies } \\
\text { reaching } 13.86 \text { against the dollar. The rand became the world's } \\
\text { second worst performing currency in } 2001 \text {, surpassed only by } \\
\text { Argentina }\end{array}$ \\
\hline
\end{tabular}

It has been argued that the same specification of the PPP hypothesis is not applicable to countries that adopt different exchange rate regimes (Liu, 1992). However, PPP as a long run phenomenon, should apply irrespective of the exchange rate regime and evidence to support this view is found in Lothian and Taylor (1996), Rogoff, Froot and Kim (2001) and Kuo and Mikkola (2001). Lothian and Taylor (1996) show that the stationary process estimated for the pre1973 data perform well in out of sample forecasting for the post -73 period, that is, before the floating regime for the industrial countries. Rogoff, Froot, and Kim (2001) show surprising stability of deviations from the law of one price over seven hundred years in England and Holland. Specifically, they show that movements in 
cross-country relative prices of the same good constituted the major source of variation in real exchange rates and that this occurs while the nominal exchange rates were far less volatile. Furthermore, Kuo and Mikkola (2001) found evidence for PPP from a panel of industrial countries over the 1947-1996 period and concluded, among other things, that PPP as a long run relationship has nothing to do with the exchange rate regime. While deviations from the law of one price (LOP) or PPP may be stationary, the sources of the deviations can interchange between the nominal exchange rate changes, the relative prices changes or both.

The empirical evidence suggests that exchange rate regime has no impact on real exchange rate behaviour in the long run. The rand-dollar bilateral real exchange behaviour should therefore provide an ideal laboratory for testing the PPP theory. Also, South Africa is an emerging market. As such, empirical evidence obtained would add new knowledge regarding PPP research in developing countries which is still in its infancy due to data constraints. The graph of rand-dollar bilateral real exchange rate series is depicted in Figure 1.

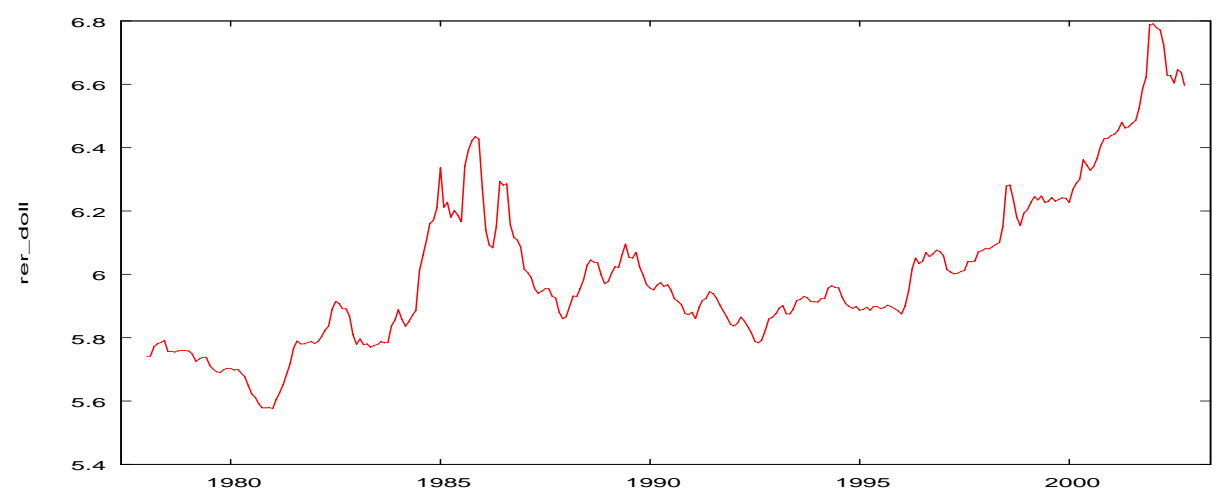

Figure1: The evolution of the rand-dollar bilateral real exchange rate

\section{The data}

Our data series cover 1978:01 to 2002:07 for the rand-dollar nominal exchange rate (used in constructing the real exchange rate) were sourced from the database of the South African Reserve Bank. The respective monthly consumer price indices for South Africa, and the United States were sourced from international finance statistics of the International Monetary Fund.

\section{U.1 Unit roots tests of purchasing power parity (PPP)}

Purchasing power parity hypothesizes that real exchange rate displays long run mean reversion. The real exchange rate of the rand is estimated as follows: 
where

$q$ is the logarithm of the rand's real exchange rate, $\mathrm{e}$ is the logarithm of the nominal exchange rate of the rand, $p$ is the logarithm of domestic CPI of South Africa, and $\mathrm{p}^{*}$ is the logarithm of USA's CPI.

It is necessary to determine the orders of integration of the variables. We begin with the familiar augmented Dickey-Fuller (ADF) and the Phillips-Perron (PP) tests for the presence of unit roots in the data. To help determine the correct specification of the unit root tests, we initially regress the log of each variable on a constant without a trend. Results of unit root tests can be sensitive to the lag selection technique employed.

Therefore, we check the robustness of our results by applying four different methods of selecting the augmenting lag length for the ADF tests. The first method chooses the number of lags (from zero to 12) that is needed to eliminate autocorrelation based on a series of Lagrange multiplier tests of the test-equation residuals. Akaike's information criterion and Schwartz's Bayesian information criterion are used to determine lag length in the second and third ADF specifications. Finally, a general-to-simple procedure (GS) is followed in the final version. In the GS case, twelve lags are originally included in the test equation. If the final lag is not significant it is dropped and the equation is re-estimated with one fewer lag. The process continues until the final lag is significant. A 5\% marginal significance level is the criterion for all tests involved in lag selection.

We also conducted the KPSS unit roots test for the null of stationarity. If the KPSS tests reject the null but the ADF and the PP tests fail to reject the null, then all the three tests support the same conclusion, that is, that the particular series in question is a unit root process. All the three tests are presented in Table 2. As expected, the typical non-rejection of a unit root in the real exchange rate of the rand is upheld. The three tests unambiguously fail to reject a unit root in the variables at a 5 percent marginal significance level. We conclude that the weight of evidence supports the presence of a unit root in the rand-dollar real exchange rate series. The series is hence I (1). This finding is consistent with those of Barr and Kahn (1995).

Table 3: Unit root test

\begin{tabular}{l|l|l|l|l|l|l}
\hline $\begin{array}{c}\text { Real exchange } \\
\text { rates }\end{array}$ & \multicolumn{3}{c|}{ Levels } & \multicolumn{3}{c}{ First differences } \\
\hline & ADF & PP & KPSS & ADF & PP & KPSS \\
\hline $\begin{array}{l}\text { Rand/Dollar } \\
\text { (lags) }\end{array}$ & $-1,01$ & $-0,58$ & 0,81 & $-3,74 * * *$ & $-11,76 * * *$ & $0,13 * *$ \\
\end{tabular}

$*, * *, * * *$ Denote significance at the $10 \%, 5 \%$ and $1 \%$ levels respectively

It is however well known that stationary series with structural breaks may appear non-stationary. Perron (1989) and Rappoport and Reichlin (1989) have suggested 
that macroeconomic data series may be stationary with a structural break in the specified function rather than being integrated series. Furthermore, Perron demonstrates that standard unit root tests can incorrectly fail to reject the unit root null hypothesis if the true data generating process is stationary with a structural break. Visual inspection of figure 1 indicates that it is possible that these series exhibit a structural break. For example, the plot shows the possibility of a structural break occurring in the mid 1980s, the late 1990s and possibly in the early 2000s. Therefore, using procedures developed by Perron (1997) and Vogelsang and Perron (1998), the unit root null hypothesis versus a no-unit root alternative is tested for this series. Recently, Sabate et al. (2003) have examined the peseta-sterling real exchange rate between 1870 and 1935 by allowing for structural breaks and have found evidence for PPP.

\section{Testing for outliers in the data: The estimation technique}

With the background of possible events dates, we estimated an ARMA model of the rand-dollar real exchange rate. On the assumption of stationarity of time series, when a conventional AR(1) model is estimated by OLS for our full sample of data, an $\mathrm{AR}(1)$ parameter of approximately 0.9 is obtained, suggesting mean reversion, but at a slow rate (hence consistent with the PPP puzzle of a real exchange rate that adjusts 'glacially' slowly to equilibrium levels; see Rogoff, 1996).

Table 4: Preliminary AR (1) parameter estimates for the rand-dollar exchange rates (1978:01-2002:07)

\begin{tabular}{l|c|c}
\hline \multicolumn{1}{c|}{ Real Exchange Rate } & AR(1) parameter & Adjusted $\mathbf{R}^{2}$ \\
\hline Rand-Dollar & 0,998 & 0,98 \\
\multicolumn{2}{|c}{$(119,6)^{* * *}$} & \\
\multicolumn{2}{|c}{ t-statistic in parenthesis. $* * *$ significant at the 1 percent level. }
\end{tabular}

t-statistic in parenthesis. $* * *$ significant at the 1 percent level.

If in a linear regression model the possible change point is known, the Chow (1960) test can be applied. The Chow test statistic has an $\mathrm{F}$ distribution under the null hypothesis of no change; hence the tabulated critical values can be used. However if the change point is not known, one possibility is to estimate an ARMA OLS regression and use the recursive test to highlight outliers in the data series. Banerjee et al. (1992) show that recursive estimation can be very useful for investigating structural change and the presence of a unit root in economic time series. Banerjee et al. (1992) derive the relevant distribution theory for recursively estimated unit root tests that allow for mean-shifts and trend-breaks under the alternative hypothesis, and that also have power against changing AR coefficients

Brown et al. (1975) suggest the CUSUM (and CUSUM square) test, in which the points of regime shifts are not required to be known in advance to detect systematic movements in regression coefficients. Ploberger and Kramer (1992) further apply the ordinary least squares residuals to the CUSUM test without the recursive residuals. Andrew (1993) also considers tests for parameter instability and 
structural change with unknown change points. Nyblom and Makelainen (1983) compare tests for the hypothesis that the regression coefficients are constant over time against the alternative that the coefficients vary according to the random walk process. Comparisons of tests for a shift in slopes of a multivariate linear time series model also have been studied by Farley et al. (1975). Ploberger et al. (1989) derive the fluctuation test on constancy of regression coefficients in linear models in which the possible change points are not required to be known.

Following Goldberg and Frydman (2001), we used recursive estimation of the residuals generated by the OLS estimates, to determine the following significant broken trend dates viz: 1985: February; 1985 August; 1986 January; 1998 July and November 2001.

Both the Additive Outlier (AO) and Innovative Outlier (IO) approaches as proposed by Perron and Vogelsang (1992) are applied in testing for a unit root with structural break. The former allows for a sudden change in the coefficients of a function while the latter permits a gradual change in coefficients. According to the innovative outlier model, the dynamic reaction to a structural change in the mean affects the level of the series the same as any other shock. Initially, the unit root test statistics from the AO and IO would account for one-time level shifts that might be identified as departures from stationarity. However, Lothian (1998) observed that the behaviour of real exchange rate series may not be adequately characterised by a single shift. Hence, the Perron-Vogelsang methodology has been extended to account for several level shifts by Clemente et al. (1998).

Accordingly, the additive outlier model is estimated in two steps as follows:

$\mathrm{y}_{\mathrm{t}}=\mu_{1}+\delta_{1} \mathrm{DU}_{1 \mathrm{t}}+\delta_{2} \mathrm{DU}_{2 \mathrm{t}}+\delta_{3} \mathrm{DU}_{3 \mathrm{t}}+\tilde{\mathrm{y}}$

$\mathrm{DU}_{\mathrm{t}}=1$ for $\mathrm{t}>\mathrm{T}_{\mathrm{b}}$ (the breakpoint), and 0 otherwise, under the null hypothesis of a unit root. At the second stage, the residuals $(\widetilde{y})$ generated by equation (2) are regressed on their lagged values and lagged differences.

$\tilde{y}=\sum_{i=0}^{k} \omega_{1 i} D T_{i t-i}+\alpha_{2} \tilde{y}_{t-1}+\sum_{i=1}^{k} c_{2} \Delta \tilde{y}_{t-i}+e_{t}$

The innovative outlier model, which allows for a change in the intercept term is estimated using equation (4) as follows.

$\mathrm{y}_{\mathrm{t}}=\mu_{3}+\delta_{3 \mathrm{i}} \mathrm{DU}_{\mathrm{it}}+\mathrm{v}_{\mathrm{ii}} \mathrm{DT}_{\mathrm{it}}+\alpha_{3 \mathrm{i}} \mathrm{y}_{\mathrm{t}-1}+\sum_{\mathrm{i}=1}^{\mathrm{k}} \mathrm{c}_{3 \mathrm{i}} \Delta \mathrm{y}_{\mathrm{t}-1}+\mathrm{e}_{3 \mathrm{t}}$

The unit roots test statistics forthcoming from the additive and innovative outlier models account for multiple shifts in the bilateral real exchange rate series.

A time trend is not included in these equations as such an inclusion would have been theoretically inconsistent with long run PPP assumption. The null hypothesis 
of a unit root is rejected in favour of the alternative of level stationarity if $\alpha$ is significantly less than zero. Rejection of the unit root null provides evidence of in support of PPP.

In both cases the potential break dates are chosen endogenously as those dates that minimize the t-statistic in the ADF regression. The lag-length for these tests is chosen by the commonly used general-to-simple (GS) method. Franses and Haldrup (1994) demonstrate that the presence of additive outliers (AO's) in a series can lead to incorrect rejections of the unit root null in ADF testing. An AO is an unusually large, temporary movement in a series. The presence of AO's may cause an integrated series to appear mean reverting, thus causing standard ADF tests to incorrectly reject a unit root in the series.

Figure 1 and the residuals from the earlier ADF test equation display evidence of Additive Outliers. These often occur in 1985, 1986, 1998 and 2001. The AO's are so severe that normality of the residuals from the ADF tests is easily rejected by a Jarque-Bera test at a 1 percent marginal significance level.

Franses and Haldrup (1994) show that the effects of the additive outliers on ADF unit root tests can be removed, without affecting the distribution of the test statistics, by including dummy variables for each $\mathrm{AO}$ in the ADF test equations. To test the robustness of our earlier results, we conduct an additional set of ADF tests of the real exchange series with dummy variables included for dates with residuals from the original ADF tests falling beyond two standard deviations.

We follow the Bai and Perron procedure for a simple univariate framework in which only one variable - the intercept - is assumed to be subject to structural breaks. The number of lags, $n$, is chosen to purge possible serial correlation in the error term using the optimal sequential procedure suggested by Campbell and Perron (1991), with the maximum lag length for $k$ set to 4 . To test for the occurrence of one break versus none, we first estimate equation without the term DU. Subsequently we estimate the same equation including DU, with DT taking all values from $k+2$ to $T$. Our innovative approach allows for the presence of multiple unknown shifts in the mean level of bilateral real exchange rate of the rand using the approach of Bai and Perron (1998)

\section{Results}

The results of our outlier analysis are presented in Tables 5 and 6. Equations (3) and (4) are estimated in first-difference forms in order to provide the estimates of $\alpha$ 1 and their respective t-statistic, for testing that $\alpha-1=0$. The estimates of $\mu$, and $\partial \mathrm{i}$ are from equation (1), whereas the estimates of $\alpha-1$ are from equations (3) and (4). The additive outliers in Table 5 reflect the impact of a series of one-time shocks. The estimates of $\partial_{\mathrm{i}}$ indicate the importance of mean shifts in the rand-dollar real exchange rate series. They are all significantly distinguishable from zero. The three additive outliers in the 1980s are tied to the 1985 debt standstill resulting from South Africa's inability to honour its international debt obligation at the time. There was a negative and significant downward mean shift in rand-dollar real exchange 
rate in 1986 January. This could be tied to a deepening political crisis that subsequently resulted in the declaration of a state of emergency by the middle of that year. It was also at this time that the rand strengthened significantly. The 1998 outlier is tied to the effect of the Asian currency crisis whereas the Rand crisis of 2001, which saw the substantial depreciation of the rand is captured by the 2001 outlier. It is interesting that these additive outliers do not coincide with political changes that took place in the 1990s, with the release of political prisoners, the unbanning of the African National Congress and the first democratic elections of 1994 and the second in 1999. This could mean that these events dates were anticipated by the market. Overall, the additive outlier model supports evidence of long run purchasing power parity due to the fact that the coefficient of $(\alpha-1)$ in our unit root test is highly insignificant.

Table 5: Additive outlier unit root tests for the rand-dollar real exchange rates

\begin{tabular}{l|c|c|c|c}
\hline $\begin{array}{c}\text { Time of Trend } \\
\text { Break }\end{array}$ & $\begin{array}{c}\boldsymbol{\partial} \mathbf{i} \\
(\mathbf{t}-\text { statistic })\end{array}$ & $\begin{array}{c}\boldsymbol{\mu} \\
\mathbf{5 , 7 8}\end{array}$ & $\begin{array}{c}\text { Auto-regressive } \\
\text { order }(\mathbf{k}=\mathbf{4})\end{array}$ & $\begin{array}{c}\text { Test for unit } \\
\text { root }(\boldsymbol{\alpha}-\mathbf{1}) \\
=\mathbf{- 0 , 6 3} \\
\mathbf{( - 5 , 4 2})^{* * * *}\end{array}$ \\
\hline $1985: 02$ & 0,44 & & \\
\hline $1985: 08$ & 0,19 & & \\
\hline $1986: 01$ & $-0,44$ & & \\
\hline $1998: 07$ & $(-8,93)^{* * * *}$ & & & \\
\hline $2001: 11$ & 0,36 & & & \\
\hline
\end{tabular}

t-statistics are in parenthesis. Critical values of $\mathrm{t}_{\alpha}$ are -5.41 and -4.80 for the $1 \%$ and $5 \%$ level of significance respectively. See Perron (1997); ${ }^{* * *}, * *$ denote significance at $1 \%$ and $5 \%$ respectively

Results of the innovative outliers model are presented in Table 6. They are generated by shocks that have at least limited persistence. The evidence of multiple mean shifts in the real exchange rate of the rand is weaker in the innovative outlier model. There was a positive and significant innovative outlier in the rand-dollar real exchange rate in 1986 January. However, the model also presents evidence of one downward mean shift in the bilateral real exchange rate of the rand against the dollar in November 2001.

The innovative outlier model does not support evidence of long run purchasing power parity due to the fact that the coefficient of $(\alpha-1)$ in our unit root test is insignificant. 
Table 6: Innovative outlier unit root tests for the rand-dollar real exchange rates

\begin{tabular}{|c|c|c|c|c|}
\hline $\begin{array}{c}\text { Time of Trend } \\
\text { Break }\end{array}$ & $\begin{array}{c}\partial \mathrm{i} \\
\text { (t-statistic) }\end{array}$ & $\begin{aligned} & \mu \\
= & -0.18\end{aligned}$ & $\begin{array}{c}\text { Auto-regressive } \\
\text { order }(k=4)\end{array}$ & $\begin{array}{c}\text { Test for unit } \\
\text { root }(\alpha-1)= \\
0.02 \\
(1.03) \\
\end{array}$ \\
\hline 1985:02 & $\begin{array}{l}-0,02 \\
(-1,4)\end{array}$ & & & \\
\hline 1985:08 & $\begin{array}{c}-0,03 \\
(-1,60)\end{array}$ & & & \\
\hline 1986:01 & $\begin{array}{l}0,05 \\
(2,49) * *\end{array}$ & & & \\
\hline 1998:07 & $\begin{array}{c}-0,00 \\
(-0,10)\end{array}$ & & & \\
\hline 2001:11 & $\begin{array}{c}-0,04 \\
(-2,45)^{* *}\end{array}$ & & & \\
\hline
\end{tabular}

t-statistics are in parenthesis. Critical values of $\mathrm{t}_{\alpha}$ are -5.57 and -5.08 for the $1 \%$ and $5 \%$ level of significance respectively. See Perron (1997)

\section{Concluding remarks.}

The paper investigates evidence of purchasing power parity in the rand-dollar real exchange rate. Traditional unit root tests fail to provide evidence of stationarity of the real exchange rate series that would have supported the purchasing power parity assumption. These results might be spurious if they do not account for structural breaks in the series of interests. As such, additive and innovative outlier models developed allow for multiple mean shifts in the bilateral real exchange rates. The additive outlier model, which capture sudden changes, present more evidence in support of purchasing power parity whereas the innovative outlier model, which captures a gradual shift in the mean of the series, supports only two shifts in the real exchange rate but does not support PPP.

\section{References}

Adler, M and Lehmann, B (1983): "Deviations from Purchasing Power Parity in the Long Run", Journal of Finance, 39, 1471-87.

Andrews, D W K (1993): “Tests for Parameter Instability and Structural Change with Unknown Change Point", Econometrica, 61, 821-856.

Bahmani-Oskooee, M (1993): "Purchasing Power Parity Based on Effective Exchange Rate and Cointegration”, World Development, 21, 1023-31.

Bai, J and Perron, P (1998): "Estimating and Testing Linear Models with Multiple Structural Changes", Econometrica, January, 66, 47-78.

Banerjee, A, Lumsdaine, R L and Stock, J H (1992): "Recursive and Sequential Tests of the Unit Root and Trend Break Hypotheses: Theory and International Evidence", Journal of Business and Economic Statistics, 10(3), July, 271-287.

Barr, G D I and Kahn, B (1995): "Testing for Purchasing Power Parity in South Africa in the Presence of Real Shocks", Journal for Studies in Economics and Econometrics, 19(1), 69-86. 
Baum, C F, Barkoulas, J T and Caglayan, M (2001): "Nonlinear Adjustment to Purchasing Power Parity in the Post-Bretton Woods Era", Journal of International Money and Finance, 20, 379-399.

Brown, R L, Durbin, J and Evans, J M (1975): “Techniques for Testing the Constancy of Regression Relationships over Time", Journal of the Royal Statistical Society, Series B, 37, 149-192.

Campbell, J Y and Perron, P (1991): "Pitfalls and Opportunities: What Macroeconomists Should Know about Unit Roots", National Bureau of Economic Research Macroeconomic Annual, 141-201, Cambridge: MIT Press, 1991.

Chow, G C (1960): "Tests of Equality Between Subsets of Coefficients in Two Linear Regression Models", Econometrica, 591-605.

Clemente, J, Montanes, A and Reyes, M (1998): "Testing for a Unit Root in Variables with a Double Change in the Mean", Economic Letters, 59, 175-182.

Corbae, D and Ouliaris, S (1988): "Cointegration and Tests of Purchasing Power Parity". Review of Economics and Statistics, 70, 508-21.

Dickey, D and Fuller, W A (1979): "Distribution of the Estimators for Autoregressive Time Series with a Unit Root”, Journal of the American Statistical Association, 74, 427-431.

Dickey, D, and Fuller, W A (1981): "Likelihood Ratio Statistics for Autoregressive Time Series with a Unit Root", Econometrica, 49,1057-1072.

Dornbusch, R (1976): “Expectations and Exchange Rate Dynamics”, Journal of Political Economy, 84, 1161-76.

Enders, W (1988): "ARIMA and Cointegration Tests of PPP under Fixed and Flexible Exchange Rate Regimes”, Review of Economics and Statistics, 70, 504-8.

Farley, J U, Hinich, M and McGuire, T W (1975): "Some Comparisons of Tests for a Shift in the Slopes of a Multivariate linear Time Series Model”, Journal of Econometrics, 3, 297-318.

Franses, P H and Haldrup, N (1994): "The Effects of Additive Outliers on Tests for Unit Roots and Cointegration", Journal of Business and Economic Statistics, 12, 471-478.

Frenkel, J A (1981): “The Collapse of Purchasing Power Parities During the 1970's." European Economic Review, 16, 145-65.

Friedman, M and Schwartz, A J (1963): A Monetary History of the United States: 1867-1960. Princeton, New Jersey: Princeton University Press, for National Bureau of Economic Research..

Froot, K and Rogoff, K (1995a): Perspectives on PPP and Long-Run Real Exchange Rates". In G. Grossman and K. Rogoff (eds) Handbook of International Economics. Amsterdam: North-Holland, $1647-88$.

Froot, K and Rogoff, K (1995b): “The Law of One Price over 700 years", Revision of NBER working Paper, May 1995, No. 5132.

Fung, H-G and Lo, W-C (1992): "Deviations from Purchasing Power Parity". The Financial Review, 27, 553-70.

Goldberg, M D and Frydman, R (2001): "Macroeconomic Fundamentals and the DM/\$ Exchange Rates: Imperfect Knowledge and the Monetary Model". Paper presented at a workshop on "Exchange Rate and Monetary Policy Issues", Institute for Advanced Policy Studies, Vienna, Austria, April 19-20.

Granger, C W J and Teräsvirta, T (1993): Modelling Nonlinear Economic Relationships, Oxford University Press, Oxford, UK. 
Hassanain, K M (2003): "Real Exchange Rate Stationarity in Developing Countries, A new Panel Test", The Journal of Academy of Business and Economics, 1(2), 76-81.

Holmes, M (2001): "New Evidence on Real Exchange Rate Stationarity and Purchasing Power Parity in Less Developed Countries", Journal of Macroeconomics, 23(4), 601-614.

Jorion, P and Sweeney, R (1996): "Mean Reversion in Real Exchange Rates: Evidence and Implications for Forecasting", Journal of International Money and Finance, 15, 535-550.

Kuo, Biing-Shen and Mikkola, A (2001): "How Sure Are We about Purchasing Power Parity? Panel Evidence with the Null of Stationary Real Exchange Rates", Journal of Money, Credit and Banking, 33(3), 769-89.

Liew, K S, Baharumshah, A Z and Lau, E (2002): "Nonlinear Adjustment to Purchasing Power Parity: Empirical Evidence from Asian Exchange Rates". Proceedings of the Asian Pacific Economics and Business Conference 2002, 902-910.

Liew, K S, Baharumshah, A Z and Lau, E (2004): "Nonlinear Adjustment towards Purchasing Power Parity in ASEAN Exchange Rates", International Journal of Applied Economics , 3( 6), November, 2004.

Liu, P C (1992): "Purchasing Power Parity in Latin America: A Cointegration Analysis", Weltwirtschaftliches Archiv, 128, 622-80.

Lothian, J (1998): "Some new Stylised Facts of Floating Exchange Rates", Journal of International Money and Finance, 17, 29-39.

Lothian, J and Taylor, M (1996): "Real Exchange Rate Behaviour: The Recent Float from the Perspective of the Past Two Centuries", Journal of Political Economy, 104, 488-509.

Luukkonen, R, Saikkonen, P and Teräsvirta, T (1988): “Testing Linearity Against Smooth Transition Autoregressive Models", Biometrika, 75, 491-499.

MacDonald, R (1996): “Panel Unit Root Tests and Real Exchange Rates”, Economic Letters 50, 7-11.

Maddala, G S and Kim, I M (1998): Unit Roots, Cointegration, and Structural Change, Cambridge University Press, 1998.

Mahdavi, S and Zhou, S (1994): "Purchasing Power Parity in High Inflation Countries: Further Evidence", Journal of Macroeconomics, 16, 403-22.

Mark, N (1990): "Real Exchange Rates in the Long Run: An Empirical Investigation", Journal of International Economics, 28, 115-36.

Meese, R and Rogoff, K (1988): "Was it Real? The Exchange Rate Interest Differential Relation over the Modern Floating Exchange Rate Period", Journal of Finance, 43, 933-48.

Micheal, P, Nobay, A R and Peel, D A (1997): "Transaction Costs and Nonlinear Adjustment in Real Exchange Rates: an Empirical Investigation”, Journal of Political Economy, 105, 862-879.

Nyblom, J and Makelainen, T (1983): "Comparisons of Test for the Presence of Random Walk Coefficients in a Simple Linear Model”, Journal of the American Statistical Association, 78, 856-864.

Oh, K (1996): "Purchasing Power Parity and Unit Root Tests Using Panel Data", Journal of International Money and Finance, 15, 405-418.

Papell, D (1997): "Searching for Stationarity: Purchasing Power Parity under the Current Float", Journal of International Economics, 43, 313-332. 
Papell, D and Theodoridis, H (1998): "Increasing Evidence of Purchasing Power Parity over the Current Float", Journal of International Money and Finance, 17 (1), 41-50.

Papell, D and Theodoridis, H (2001): "The Choice of Numeraire Currency in Panel Tests of Purchasing Power Parity", Journal of Money, Credit, and Banking, 33, 790-803.

Patel, J (1990): "Purchasing Power Parity as a Long-Run Relation", Journal of Applied Econometrics, $5,367-79$.

Perron, P (1989): "The Great Crash, the Oil Price Shock, and the Unit Root Hypothesis", Econometrica, 57, 1361-1401.

Perron, P (1997): "Further Evidence on Breaking Trend Functions in Macroeconomic Variables", Journal of Econometrics, 80, 355-385.

Perron, P and Vogelsang, T (1992): "Nonstationarity and Level Shifts with an Application to Purchasing Power Parity”, Journal of Business and Economic Statistics, 10 (3), 301-320.

Ploberger, W and Kramer, W (1992): "The CUSUM Test with OLS Residuals, Econometrica, 60, 271285.

Ploberger, W, Kramer, W and Kontrus, K (1989): "A New Test for Structural Stability in the Linear Regression Model", Journal of Econometrics, 40, 307-318.

Rappoport, P and Reichlin, L (1989): "Segmented Trends and Non-stationary Time Series", The Economic Journal, 99, 168-177.

Rogoff, K (1996): “The Purchasing Power Parity Puzzle”, Journal of Economic Literature, 34, 647668 .

Rogoff, K, Froot, K A and Kim, M (2001): The Law of One Price Over 700 Years, IMF Working Papers 01/174, International Monetary Fund.

Sabate, M, Gadea, M D and Serrano, J M (2003): "PPP and Structural Breaks. The Peseta-sterling Rate, 50 years of a Floating Regime", Journal of International Money and Finance, 22 (5), 613-727.

Salehizadeh, M and Taylor, R (1999): “A Test of Purchasing Power Parity for Emerging Economies”, Journal of International Financial Markets, Institutions and Money, 9, 183-193.

Sarantis, N (1999): "Modelling Non-linearities in Real Effective Exchange Rates", Journal of International Money and Finance, 18, 27-45.

Sarno, L (2000a): "Real Exchange Rate Behaviour in High Inflation Countries: Empirical Evidence from Turkey, 1980 - 1997” Applied Economics Letters, 7, 285-291.

Sarno, L (2000b): "Real Exchange Rate Behaviour in the Middle East: A Re-examination", Economics Letters, 66, 127-136.

Sarno, L (2001): "The Behaviour of US Public Debt: a Nonlinear Perspective”, Economics Letters, 74, $119-125$.

Taylor, M P and Peel, D A (1997): "Nonlinearities in Real Exchange Rate Adjustment During the Recent Float: Empirical Evidence and Monte Carlo Analysis", Discussion Paper, Institute of Economics and Statistics, University of Oxford.

Taylor, M P and Peel, D A (2000): "Nonlinear Adjustment, Long-run Equilibrium and Exchange Rate Fundamentals", Journal of International Money and Finance, 19, 33-53.

Taylor, M P and Sarno, L (1998): "The Behaviour of the Real Exchange Rate During the Bretton Woods Period" Journal of International Economics, 46, 281-312. 
Tsay, R S (1986): “Time Series Model Specification in the Presence of Outliers", Journal of the American Statistical Association, 81(393), March, 132-141.

Vogelsang, T J and Perron, P (1998): “Additional Tests for a Unit Root Allowing for a Break in the Trend Function at an Unknown Time”, International Economic Review, 39, 1073-1100.

Wu, Y (1996): “Are Real Exchange Rates Non-stationary? Evidence from a Panel-Data Test”, Journal of Money, Credit, and Banking, 28, 54-63. 